\title{
'NIERA-T-ON LE POUVOIR DES ARTS?' REVISITING JACQUES-LOUIS DAVID AT THE 1846 EXHIBITION IN THE BAZAR BONNE-NOUVELLE
}

Il [David] s'est agenouillé devant une nature haineuse, féroce, hideuse, et à force de génie il a su l'ennoblir, sans mentir un instant, l'élever à toute la hauteur des plus beaux ouvrages de l'antiquité. Niera-t-on le pouvoir des arts? ${ }^{1}$

On 29 March i 846, at the AGM of the Association des artistes peintres, sculpteurs, architectes, graveurs et dessinateurs, Adrien Dauzats reported on the success of its activities since the founding of the Association eighteen months earlier. $^{2}$ The exhibition of paintings mounted in the galleries of the Bazar Bonne-Nouvelle for nine weeks between I I January and I 5 March that year had attracted 25,000 visitors and generated 31,000 francs from catalogue sales, admission charges, and donations. ${ }^{3}$ A lavish society ball, the 'fête dite de l'association des artistes', had taken place on 3 I January in the Salle de l'Odéon and here too the receipts after deduction of costs had risen to the occasion. ${ }^{4}$ The proceeds from both events had been used to purchase additional government stock which, by the time Dauzats reported to the AGM, was paying an annuity of 12,000 francs into the combined Caisse de secours et pensions of the three associations of artists, musicians, and playwrights. ${ }^{5}$ Due homage was

' Anon., 'Exhibition de l'association des artistes peintres, sculpteurs, architectes et graveurs: Louis David', Fournal des artistes, 25 January i 846 , pp. 25-27 (p. 26).

2 'Assemblée générale: Compte-Rendu fait par M. A. Dauzats, l'un des secrétaires, au nom du Comité de l'Association', Annuaire de l'Association des artistes peintres, sculpteurs, architectes, graveurs et dessinateurs (Paris: n.p., i 846), pp. I 5-36 (further references to this article are identified as 'Dauzats'). This address, together with the relevant minutes of the meetings of the Association during 1845 and 1846 , and some of the articles on the exhibition that appeared in newspapers and periodicals of the time, were reprinted in the exhibition catalogue Le Baron Taylor, l'Association des artistes et l'exposition du Bazar Bonne-Nouvelle (Paris: Fondation Taylor, I 995). This catalogue also contains Bruno Foucart's introduction to the critical reception of the 1846 exhibition, 'La critique artistique devant l'exposition du Bazar Bonne-Nouvelle ou les retours de David et Ingres' (pp. 2 I-3 I). In his otherwise very informative article, Foucart mentions only in passing the specific critical reception of David's Marat, with which I shall be concerned here.

3 Charles Lenormant confirmed Dauzats's figure: 'Aussi le succès de l'exhibition a-t-il dépassé toutes les espérances: les recettes, depuis six semaines, n'ont guère été au-dessous de 500 francs par jour' ('Exposition au profit des artistes malheureux', Le Correspondant, February i 846, pp. 664-74 (p. 664, italic original)).

4 In the Moniteur des arts, which, together with the fournal des artistes, Dauzats had identified (pp. 30-3 I ) as the 'fidèles auxiliaires' of the Association's activities, Auguste Jal engagingly stated 'On a songé à intéresser les femmes par un bal, et les hommes par une exposition d'ouvrages sérieux' ('Exposition d'ouvrages de l'école française', Moniteur des arts, 5 I (i 8 January i 846), I 93). For an account of the founding of the Association and of the organization of the exhibition and ball, see Paul Ambille's introduction to Le Baron Taylor, pp. 9-i 9. For a contemporary account of the Odéon's sumptuous ballroom and of the ball, managed by fifty 'dames patronnesses' drawn from the elite of July Monarchy society, see Anon., 'Courrier de Paris', L'Illustration, 3 I January i 846 , p. 338 . According to Dauzats, the ball had generated a further 30,000 francs for the Caisse de secours.

5 The three associations, founded and presided over by Baron Taylor, 'comptent aujourd'hui 400 mille francs et plus de douze mille francs de rente! Ainsi à peine née, l'idée féconde de

Modern Language Review, 102 (2007), 672-86

(C) Modern Humanities Research Association 2007 
paid to the members of the royal family who had honoured the exhibition with their presence and with further unspecified 'marques splendides de leur munificence' (Dauzats, pp. $\left.3 \mathrm{I}^{\mathrm{I}-32}\right){ }^{6}$ All who had contributed to its organization and management were warmly thanked, and as an example of the many handsome philanthropic gestures that the event had encouraged, Dauzats read out a letter, 'qui honore également celui qui l'écrit et ceux qui la reçoivent', and in which the art critic Étienne-Jean Delécluze informed him that he was donating to the Caisse de secours the $\mathrm{s} 00$ francs fee that he had received from the Fournal des débats for his review of the exhibition. ${ }^{7}$ Little wonder that, as Dauzats put it (p. 35), 'la lecture de ce Rapport, écoutée avec le plus vif intérêt, souvent interrompue par des témoignages d'approbation, se termine par des applaudissements de l'Assemblée'.

Exhibitions of contemporary art in aid of charity were few and far between during the July Monarchy, and the success of the Bonne-Nouvelle exhibition was unprecedented. ${ }^{8}$ The patronage of the July Monarchy's social and professional elites and the willingness of distinguished collectors to lend their works were important factors in this success, but the key element was the prestige of the artists whose work was exhibited there. Chronologically the earliest work on show was Greuze's I 763 Portrait de Fohann Georg Wille, the latest, Ingres's La Vicomtesse Othenin d'Haussonville, completed in 1845 , but the exhibition eventually contained ninety-six works by nineteen artists, six living and thirteen deceased, the majority of whom were more or less closely associated with the "école de David'. ${ }^{9}$ On the morning of the opening, an anonymous author, in all likelihood one of the exhibition's organizing committee (and whose comment on the power of arts is quoted at the beginning of this article), explained in the Fournal des artistes: 'L'idée-mère de l'exposition était de captiver l'attention publique par quelques œuvres de nos derniers grands maîtres et celles des artistes qui, retirés dans leurs tentes, n'avaient pas paru au Salon depuis quelques années', by which he meant 'des œuvres seules de MM. Ingres, L. [sic] Delaroche, A. Scheffer, L. David, Gérard et Girodet'. ${ }^{\circ}$ 'This declared aim of bringing together for philanthropic reasons six big names in a pleasing symmetry of three modern and three contemporary, each possessing major crowd-pulling, fund-raising potential, is, however, nowhere mentioned in the minutes of the Association's meetings and has all the signs of having been thought up late in

l'association dispose déjà d'une somme de ı००० francs par mois en faveur de l'intelligence malheureuse' (Dauzats, p. 34).

6 'LL.AA.RR. Madame la Duchesse d'Orléans, le Prince de Salerne, le Prince et la Princesse de Joinville, le Duc et la Duchessse d'Aumale, le Duc de Montpensier ont tour à tour visité notre exhibition' (Dauzats, p. 32).

7 'Exposition des ouvrages de peinture dans la galerie des Beaux-Arts, boulevard BonneNouvelle, 22', Fournal des débats, 28 January i 846, unpaginated.

${ }^{8}$ For earlier examples of exhibitions in aid of charity see Foucart, 'La critique artistique', p. 2 I .

9 For a detailed account of Ingres's participation in the exhibition see Andrew Shelton's excellent study, Ingres and his Critics (Cambridge: Cambridge University Press, 2005), pp. I46-83.

Io Anon., 'Exhibition de l'association des artistes peintres, sculpteurs, architectes et graveurs', Fournal des artistes, I I January i 846 , pp. 9-i ( p. 9). The three 'derniers grands maîtres' had died within the preceding two decades (David in 1825 , Girodet in 1824 , and Gérard in 1832 ); of the three contemporary artists 'retirés dans leurs tentes', Ingres had not submitted work to the annual Fine Art Salon since I 834, Delaroche since I 837, and Scheffer since i 839 . 


\section{Facques-Louis David in the Bazar Bonne-Nouvelle}

the day to counter suggestions that Delacroix had been deliberately excluded to appease Ingres or to prevent the exhibition from descending into an unseemly repetition of the classical vs. Romantic arguments that divided the annual Salon. ${ }^{\text {I }}$ However the final list of exhibits may have been established, it was not what had originally been intended, as the minutes of the Association's meetings during I 845 make clear. Following the announcement made on 3 I May that year that ' $M$. Ingres accepte le titre de membre honoraire du Comité et qu'il offre toutes ses œuvres pour l'exposition projetée au profit de l'Association' , ${ }^{2}$ the Committee was evidently operating on the assumption that the proposed exhibition would consist of a retrospective of the work of Ingres alone. The decision not to limit it in this way was the result of a suggestion apparently made by Ingres himself and reported to the Committee on 7 November, only two months before the exhibition was due to open. ${ }^{13}$

Within weeks of Ingres's change of heart, offers were being received and suggestions made in relation to work by other members of the Association. More important, however, the Committee had by then also accepted an offer from David's daughter, Baroness Jeanin, to make available for the exhibition some of her late father's work in her possession. ${ }^{\text {I4 }}$ It may also have been her offer which triggered that made by David's son, Eugène, to lend La Mort de Marat of I 793. ${ }^{15}$ Together with the La Mort de Socrate of I 787, made available by the Marquis de Verac, the Marat displayed David's pre-eminence in what Delécluze called 'la peinture d'histoire proprement dite [Socrate]' and 'la peinture d'histoire contemporaine [Marat], dont l'une a été régénérée en France

I Despite the disingenuous assertion in the fournal des artistes that 'si quelque artiste se croit frappé [. . .] d'une exclusion préméditée, il a le plus grand tort' (p. 9), the editorialist in L'Artiste suggested that Ingres's supporters on the organizing committee had been afraid that Delacroix's colourism would put their painter in the shade: 'Les enthousiastes de M. Ingres ont-ils donc craint de le faire pâlir devant la couleur de M. Delacroix?' (L'Artiste, i i January i 846, p. I76). Admittedly L'Artiste was, as we shall see, persistently hostile to Ingres, but Baudelaire, we remember, claimed to have on good authority the antagonism to Delacroix on the exhibition's organizing committee (in Euvres complètes, ed. by Claude Pichois, 2 vols (Paris: Gallimard, I 976), II, 4I 4). Even the Davidian Delécluze commented, albeit neutrally, on the absence of Delacroix ('Exposition des ouvrages de peinture', unpaginated). As Foucart points out ('La critique d'art', p. 25), the Committee relented only very late in the day, when the exhibition had only a fortnight left to run, and admitted a few works by Delacroix and Decamps.

${ }^{12}$ For the minute of the meeting see Le Baron Taylor, p. I I 5. Shelton describes the Committee's apparent assumption that Ingres wished to have a 'multi-work, single-artist exhibition' as 'rather extraordinary [. . .] given the rarity of such exhibitions in Paris at the time' (Ingres and his Critics, p. I 49), but its search for a locale for the exhibition reinforces the impression that this was indeed what it assumed, for the essential criterion as far as location was concerned was that of being 'convenable pour l'exhibition des tableaux offerts par M. Ingres' (Le Baron Taylor, p. I I 8). In its meeting of $\mathrm{I} 7$ October $\mathrm{I} 845$, the gallery in question was Dauzats's own home, but evidently it did not pass the test, for two weeks later 'MM. Duval Le Camus et Foyatier sont chargés de demander à M. Ingres si une exposition de ses tableaux, dans le local ci-dessus [1'École des Beaux-Arts] lui conviendrait' (Le Baron Taylor, p. i 20, meeting of 3 I October i 845).

r3 'M Duval Le Camus a visité M. Ingres qui désire ne pas exposer seul et désirerait exposer concourramment avec d'autres membres de la Société' (Le Baron Taylor, p. I 2 I). Shelton argues persuasively that Ingres may have 'lost his nerve [. . .] at the idea of carrying the inaugural exhibition of such an important organisation on his own' (Ingres and his Critics, p. I 5 I). The report to the Committee also appears to confirm that the idea of exhibiting work by first-generation Davidians did not come from Ingres and was not yet on the agenda at the end of October I 845 .

I4 The text of the Committee's letter of thanks to the Baroness is inserted between extracts of minutes of the meetings of $2 \mathrm{I}$ and 28 November (Le Baron Taylor, p. 123).

${ }_{15}$ On 26 December the Committee thanked him for his offer (Le Baron Taylor, p. I 28). 
et l'autre instituée chez nous par lui'. ${ }^{6}$ The two paintings had in common the representation of the death of a Davidian 'hero'. ${ }^{17}$ Two decades earlier, on the occasion of the sale of David's work after his death, Delécluze had noted in his diary in relation to the Marat: 'Il est fâcheux pour David que ce soit un aussi triste sujet qui l'ait inspiré. Le personnage de Marat, si hideux et qui, de plus, deviendra si obscur, ne permettra guère que ce tableau soit exposé.' ${ }^{18}$ In 1846 , however, it may have seemed to David's heirs that in the context of an exhibition which clearly enjoyed powerful official support from the regime and which, organized in aid of charity by an association whose philanthropic mission and associative principles may have appeared to offer the conditions for a more neutral, less sectarian response to David's work, this was as good a time as any to test the waters again in both the artistic and commercial sense. By the time the exhibition opened, twelve works by David (nine paintings and three drawings) had been made available to the organizers and a self-portrait was later incorporated into the Suite des suppléments.

There can be no doubt that, as Shelton states, Ingres's work 'constituted the single greatest attraction of the Bonne-Nouvelle exhibition' and that this attraction was due to the extent to which 'the entirety of the artist's career seems to have been recapitulated' on the walls of the exhibition. ${ }^{19}$ No other artist's work, not even the David exhibits, could compete with that of Ingres in terms of the chronological and stylistic range that Ingres had quite deliberately set out to display. Yet for those members of the Association's organizing committee who were hostile to Romantic painting, a second focus for their hostility towards it was provided by the late addition of David's work. The exhibition's consecration of Ingres as France's greatest living painter was, from their point of view, reinforced by the rehabilitation of David, the initiator of modern French art's return to the tradition of 'la grande peinture' which Ingres had inherited. The reviewer in the Fournal des artistes, evidently not one for nuances, declared that 'une horde de novateurs, la hache en main, s'est ruée avec toute la ferveur des pygmées ou avortons contre ce colosse [David]' but that now, thanks to the generous collectors willing to 'se dessaisir un moment de si précieux trésors, la gloire de leurs foyers, la douce joie de leur vie', French art would be witness to 'une réhabilitation, à une réaction qui, nous en doutons aujourd'hui moins que jamais, aura une grande influence sur l'avenir de l'art et des artistes' ${ }^{20}$

Support for David's rehabilitation was not confined in 1846 to conservative elements committed to a neo-classical revival. At the opposite end of the artistic and political spectrum from that occupied by the Fournal des artistes, Prosper Haussard, in the republican daily Le National, took exception to the privileged position enjoyed by Ingres's work in the exhibition:

Et d'abord, rendons à David ce qui lui est dû; à David le premier honneur, la première

I6 'Exposition des ouvrages de peinture'.

${ }^{17}$ 'The anonymous reviewer in the fournal des artistes stated in his second article on the David work on show that the two paintings had 'de l'analogie l'une avec l'autre, par leur résultat, c'està-dire par la mort des héros' (25 January i 846, p. 26).

I8 Diary entry of 23 March i 826 , quoted by Jean-Rémy Mantion, 'Enveloppes à Marat David', in La Mort de Marat, ed. by Jean-Claude Bonnet (Paris: Flammarion, I 986), pp. 204-32 (p. 206).

${ }^{19}$ Ingres and his Critics, p. I 55 .

${ }_{20}$ On i 8 January i 846 , p. I 7 , and 25 January, p. 25. 


\section{Facques-Louis David in the Bazar Bonne-Nouvelle}

place parmi les illustres morts comme parmi les vivans plus ou moins illustres de cette galerie! Aussi bien, MM. du comité de la Société des artistes lui ont manqué gravement. Jeter David dans le pêle-mêle et sans égard au voisinage, accrocher plutôt qu'exposer à la première place venue, à l'entrée d'un couloir, la Mort de Socrate et le Marat, deux chefs-d'œuvre à divers titres, deux pages de cette force et de ce caractère, c'est une suprême inconvenance: c'est profaner l'art et l'une des plus grandes mémoires de l'école française! Il faut qu'on le sache bien, nul aujourd'hui encore n'a le droit de trôner au-dessus de David. ${ }^{21}$

He even went as far as to say that Ingres, had he been consulted, would have wished to see the two paintings hanging in his separate gallery space in place of his own Edipe et le Sphinx. ${ }^{22}$

This emphatic support for David and what Haussard called his 'classical and national school' was one end of the spectrum of pro-republican opinion; at the other was Paul Mantz, who claimed that the Bonne-Nouvelle exhibition had been mounted solely to ensure that 'cette école [néo-classique] disparaisse pour l'éternité dans le gouffre sans fond où s'engloutissent les vieilles erreurs'. ${ }^{23}$ Between the two extremes represented by Haussard and Mantz, the best-known republican critic of the period, Théophile Thoré, expressed his admiration for the way in which David had continued what he called the 'tradition philosophique de l'école française', inherited from Poussin, but regretted that he was 'moins peintre que sculpteur', and that, like his most famous pupil, Ingres, he had been prevented by self-imposed technical limitations, what he called 'leur pratique volontairement bornée', from achieving his intellectual ambitions in his work. ${ }^{24}$

For those such as Haussard and the anonymous reviewer in the Fournal des artistes who were united across the contemporary artistic and political divide in their support for the rehabilitation of David, it was asking a great deal of his work on show in the Bazar Bonne-Nouvelle to achieve it. It was not just that it could not compete in terms of impact with the Ingres exhibition, set apart in its own gallery space which Ingres had himself organized and to which the rest of the show served as a sort of antichamber. ${ }^{25}$ It was also that the majority of the David exhibits themselves could not be described as major works in their own right. For the best-known of them, La Mort de Socrate, the critics had available

${ }^{21}$ 'Exhibition de tableaux de l'école moderne française au profit de la Caisse des secours et pensions de la Société d'artistes', Le National de I834, 23 March i 846, unpaginated.

${ }_{22}$ 'M. Ingres, qui professe une admiration profonde et un respect filial pour son premier maître, n'a pas été consulté sans doute.' Had he been, his supporters on the organizing committee 'auraient, par exception, admis dans le sanctuaire ces deux œuvres vénérables, au lieu de sacrifier ainsi le grand maître à l'élève, si grand que celui-ci se soit fait à son tour' ('Exhibition de tableaux de l'école moderne française', unpaginated). Given what we know of Ingres’s determination to retain control of the exhibition of his own work, it is hard to believe that Haussard was not just making mischief here.

23 'Une exposition hors du Louvre', L'Artiste, i 8 January i 846 , pp. i 86-89 (p. i 87). 'Je ne sais point, dans toute l'histoire de l'art en France, de page aussi triste que celle où la république, l'empire et la restauration ont écrit les noms de David, de Girodet, de Guérin, et de quelques autres' (ibid.). In the Catholic daily L'Espérance, Charles ver Huell rubbished Mantz's argument in the third of his four articles on the exhibition ('Exposition d'ouvrages de peinture dans la Galerie des beaux-arts, boulevard Bonne-Nouvelle, $\mathrm{n}^{\circ}$ 22, au profit de la caisse de secours et pensions de la société des artistes peintres, sculpteurs, graveurs, architectes et dessinateurs', L'Espérance, 8 (27 January i 846), I-3 (p. I)).

${ }_{24}$ 'Exposition de la Société des artistes', Le Constitutionnel, I 8 January I 846, pp. 203-04 (p. 203).

25 See Shelton's account of these arrangements in Ingres and his Critics, p. I 62. 
the well-established philosophical and formal programme associated with the 'beau idéal' enshrined in the classical canon. Here Delécluze, the keeper of the Davidian flame among the art critics, led the way and others followed. ${ }^{26}$ But quite apart from the increasing scepticism which the idea of the 'beau idéal' was meeting by the mid-century, the work's familiarity through engravings may have reduced its impact in $1846 .{ }^{27}$ It was generally felt that the Bonaparte au Grand-Saint-Bernard of I80 I was over-theatrical but what else could you expect, the critics asked, when Bonaparte himself had told David how he wanted it painted ${ }^{28}$ Even the reviewer in the Fournal des artistes had to admit "la faiblesse relative ${ }^{29}$ of Télémaque et Eucharis of 1818. As for the portraits, the largest single category of his work on show (Louise Trudaine, c. I79I-92; Gaspar Meyer, I795; Antoine Mongez and his wife, I812; Madame Charlotte David, I 8I3; Mademoiselle Fleury, unlocated), they were competing against Ingres's work in a genre in which the latter's supremacy was widely acknowledged, even among those unsympathetic to his work in other genres. The three major Ingres portraits on show in the Bazar Bonne-Nouvelle-the Louis François Bertin of I 832, Le Comte Mathieu-Louis Molé of I 834, and the latest arrival, shown in public for the first time, La Vicomtesse Othenin d'Haussonville-evidently appeared to overshadow the David portraits exhibited. But the essential issue in I 846, as far as David's position in the changing French art field of the late July Monarchy was concerned, was the Marat.

As we have seen, by that time support for and opposition to David transcended artistic and political divisions in France. The revolution of July i 830 had brought an end to the vendetta pursued by the Bourbon regime against the painter who, as a member of the Convention Nationale in I793, had voted for the death of the king. ${ }^{\circ}$ The Marat painting, however, was still largely unknown by the end of 1845 , for the reason already indicated by Delécluze twenty years earlier but also because, unlike the Socrate, no engraving of the Marat existed

\footnotetext{
${ }^{26}$ Delécluze: 'David a fait preuve dans le Socrate d'une recherche de style, d'une étude de l'expression et d'un calme dans l'ensemble de la scène qui indiquent le retour vers l'étude des ouvrages de l'antiquité et de ceux de Le Sueur et du Poussin' ('Exposition des ouvrages de peinture'); Lenormant: 'Autant les têtes des jeunes gens debout derrière le philosophe rappellent les types de convention de l'école de Vien, autant le Socrate annonce un maître rentré à pleines voiles dans le sillon oublié de Lesueur et de Poussin. Je crois même qu'il serait difficile de trouver une figure où un moderne ait usé de l'antique avec plus d'intelligence et de vie' ('Exposition au profit des artistes malheureux', p. 669).

${ }^{27}$ Of La Mort de Socrate, J.-J. Arnoux wrote: 'Nous croyons tout à fait inutile de décrire la scène traitée par lui: le public la connaît assez, et, parmi ceux qui n'ont pas admiré l'original [in the Louvre], il n'est personne qui n'en ait vu cent fois la reproduction par la gravure ou la lithographie' ('Revue des beaux-arts: exposition de tableaux dans la Galerie Bonne-Nouvelle', L'Époque, io February i 846 , unpaginated).

${ }^{28}$ Thoré: 'Le cheval pie, dressé sur ses jarrets, escalade les Alpes, comme le Pégase de la guerre; un manteau orange flotte comme des ailes autour du jeune homme au profil aquilin. Mais comment critiquer cette pose théâtrale, quand on sait que la composition est en quelque sorte de Bonaparte lui-même, qui avait dit à son peintre: "Faites-moi calme sur un cheval fougueux". Le mot est superbe et les lignes le traduisent à merveille; mais la couleur est sèche et discordante. L'excellent statuaire que Louis David!' (Le Constitutionnel, 9 February i 846, unpaginated).

29 'Exhibition de l'association des artistes', 25 January i 846, p. 27.

${ }^{30}$ See Nicos Hadjinicolaou, 'Jacques-Louis David au premier Salon de la monarchie de Juillet', in Scritti di storia dell'arte in onore di Federico Zeri, 2 vols (Milan: Electa, I 984), II, 908-i 5 (p. 908).
} 


\section{Facques-Louis David in the Bazar Bonne-Nouvelle}

from which the work could have been made familiar through reproduction. ${ }^{3}$ What remains to be seen here, therefore, is the response of the art critics and journalists to the discovery of the painting at the Bazar Bonne-Nouvelle. ${ }^{32}$

The most enthusiastic response was that of Haussard in Le National, who described the work as 'cette fiévreuse et sanglante peinture pour laquelle il fallait une âme et un pinceau de fer trempés tout exprès, morceau unique d'art et de passion, naïf jusqu'à la crudité, simple jusqu'à l'horreur, et qui vous laisse un long saisissement'. ${ }^{33}$ As for many other critics, the impact of the Marat on Haussard was direct and physical. Whether in awe or disgust or, more often, some complex mixture of the two, it made, he said, the spectator shudder. Recovering his poise, he channelled his visceral response through an art-historical discourse, in which he attributed the work's power to its modern, realistic mode of representation. This, he claimed, was unique in David's output in being stripped of the classical idiom in which the artist had hitherto worked but which he had repudiated in his outrage at the crime committed against the ami $d u$ peuple. By means of this unprecedented pared-down style, David had transformed what for a mid-nineteenth century French public was Marat's physical

${ }^{3}$ I On $5_{5}$ November 1793 the Convention decided to finance an engraving of the Marat, which was never realized. See the exhibition catalogue facques-Louis David, I748-I825 (Paris: RMN, I989), p. 282.

${ }^{32}$ The critical reception of the Marat in the Bonne-Nouvelle exhibition is largely absent from the David literature, except of course with regard to Baudelaire's article, 'Le musée classique du Bazar Bonne-Nouvelle'. Such was the subsequent prestige of his art criticism that the article has been widely assumed to be the founding text of this critical reception, with the result that other contemporary reviews were largely ignored until the exhibition catalogue Le Baron Taylor, and Foucart's accompanying article, resurrected them. Mantion, for example, asserted: 'C'est sous la plume de Baudelaire que l'on trouve le texte fondateur' ('Enveloppes à Marat David', p. 207), and William Vaughan and Helen Wilson, who gave it pride of place at the beginning of their introduction to David's 'The Death of Marat' (Cambridge: Cambridge University Press, 200o), agreed that Baudelaire had produced 'the "classic formulation" of the picture' (p. i 8). Similarly, the catalogue of the major I 989 David exhibition (see previous note) refers only to Baudelaire in its bibliographical note on the critical reception of the painting in i 846 . Baudelaire's account of David's fusion of realism and idealism in the Marat was expressed with characteristic sharpness-'Tous ces détails sont historiques et réels, comme un roman de Balzac [. . .] Ceci est le pain des forts et le triomphe du spiritualisme; cruel comme la nature, ce tableau a tout le parfum de l'idéal' (Euvres complètes, II, 409-IO) - but, as we shall see, it was not in itself unusual in $\mathrm{r} 846$. In the conference held to accompany the bicentenary David exhibition, three papers on the Marat shed much new light on its iconography and formal features (Matthias Bleyl, 'Marat: du portrait à la peinture d'histoire', Jörg Traeger, 'La Mort de Marat et la religion civile', and Klaus Herding, 'La notion de temporalité chez David à partir de Marat', in David contre David: actes du colloque organisé au musée du Louvre par le service culturel du 6 au Io décembre I989, sous la direction de Régis Michel, 2 vols (Paris: La Documentation Française, I 993), I, 38 I-97, 399-4I 9, and 42 I-39 respectively) but, like T. J. Clark's very important article 'Painting in the Year Two' (Representations, 47 ( I 994), I 3-63), not addressing reception issues, they did not mention the Bonne-Nouvelle exhibition. In an excellent article in David contre David, Neil McWilliam presents the different nineteenth-century representations of David the man, painter, and conventionnel and the manner in which they were incorporated into more general contemporary debates on reason and nature, but does not refer to the Bonne-Nouvelle exhibition ('Les David du XIx ${ }^{\mathrm{e}}$ siècle', ibid., II, I I I 7-35). He comments on the Marat in relation to accounts of David which saw him as 'un individu emporté par les événements, dont l'idéologie trop abstraite et désincarnée lui interdit toute emprise ferme sur la réalité' (pp. I I 27-28) and which were clearly important in $\mathrm{i} 846$, but his examples are taken from critics writing during the Second Empire. The interest of the Bonne-Nouvelle exhibition is to see how strategies designed to dissociate the painter from the conventionnel or to reintegrate his work, whether positively or negatively, within a continuous narrative of the French 'school' of painting coped, or failed to cope, when confronted with the reality of David's representation of the demonized Marat.

33 'Exhibition de tableaux de l'école moderne française'. 
and moral disfigurement and demagogue villainy into an object of beauty and horror, one which confronted visitors to the Bazar Bonne-Nouvelle with both their dream of the Revolution and nightmare of the Terror. Though the Mort de Socrate and the Marat were, therefore, poles apart, together they demonstrated the full range of David's mastery, which had 'fait éclore une nouvelle renaissance de cette antiquité qui ne peut mourir et refleurit toujours comme la beauté, rajeunit comme la nature, éternellement' ${ }^{34}$ No other critic accepted as unreservedly as the republican Haussard the evidence that the two works appeared to provide of the enduring relevance of David's achievement to the cause of a modern, national art.

In L'Époque of ro February i 846 J.-J. Arnoux described in a similar vein what he took to be the typical response to the Marat:

On éprouve devant cette peinture un sentiment étrange, indéfinissable, quelque chose qui tient d'une fascination douloureuse; on en détourne les yeux pour les y ramener presqu'à l'instant. Tantôt c'est une impitoyable horreur, un dégoût invincible, tantôt c'est presque de la pitié que vous inspire le squalide lépreux, le fou sanguinaire. Toutepuissance magique de l'art! faire éprouver à notre génération de la pitié pour Marat! ${ }^{35}$

At the outset of his article Arnoux had announced his sympathies, artistic as well as political, for July Monarchy juste milieu orthodoxy: 'Pour nous, nous ne concevons pas plus qu'on offre David en sacrifice à nos grands coloristes vivans, que nous ne comprenons l'engouement exclusif de certains critiques pour David et son école.' In terms of Arnoux's instinct for compromise, however, Marat was a cas limite. Half a century on from the Terror, he was still torn between revulsion at the sight of the fanatic who was one of its principal perpetrators and the desire to see and experience for himself the mystery of the attraction of Marat for David, 'le peintre de la nation', as Arnoux called him. He preceded his description of the painting itself with lengthy extracts from David's speeches to the Convention and enumeration of his initiatives in favour of art and its place in national life. When he came to David's work on show, he began with the Socrate, in which he tempered conventional praise of its 'majesté auguste' and 'unité merveilleuse d'action' with equally conventional reservations in relation to contour and lack of chiaroscuro. ${ }^{36}$ When he came to the Marat, however, he found that, despite the repugnance he felt for its subject, the power of David's performance swept reservations aside:

Jamais David ne s'est montré plus complet que dans le Marat: composition simple, dessin large, touche hardie, expression dramatique, coloris plus vigoureux que dans toutes ses autres toiles connues du public, sans exempter le Sacre de l'Empereur, coloris qui étonne presque dans une œuvre de David, qui fait pressentir que les Pestiférés de Jaffa [by Gros] sortiront de son école, qui enfin rappelle les puissantes teintes grises que Lesueur a employées dans la Mort de Saint Bruno. Il y a çà et là des demi-teintes d'une vigueur et d'une transparence merveilleuse. C'est que David avait à peindre ici

34 Ibid.

35 'Revue des beaux-arts'; all quotations from Arnoux in the discussion that follows are from this source.

${ }_{36}$ 'Nous ne dirons rien des contours: on sait leur sécheresse. Mais le clair-obscur, hors duquel il n'y a pas de salut pour le peintre, comment est-il entendu? D'une façon nulle. Comment l'artiste, qui plaçait le Corrège si fort au-dessus des plus grands peintres, a-t-il pu distribuer ainsi les lumières et les ombres?' 
un de ces drames palpitans dans la représentation desquels le génie se surpasse presque toujours lui-même.

Faced with the painting, Arnoux went through one constituent element of the painter's art after another to account for the way in which David, under the impact of the exceptional political drama, had surpassed himself in harnessing all the transformative power of his medium. The great crisis, in which the artist had, in Arnoux's terms, temporarily taken leave of his senses and in which 'la poursuite de la quasi-déification de Marat a été une réelle, une longue, une déplorable monomanie', one reinforced in David's case by 'l'amitié, ce sentiment souvent aveugle comme l'amour', had propelled the artist beyond his self-imposed technical limitations into a miraculous conjunction with the past and future of French art. In the process David had made the Revolutionary school that he embodied a conduit between the classical tradition represented by Lesueur and the colourism and naturalism of the new Romantic school. ${ }^{37}$ In this account of Marat, David the conventionnel régicide was transcended by David the momentarily deranged genius, who, in the grip of lethal passions of politics and friendship and inspired by the expressive powers of his medium, had created the decisive link in the historical chain between the founders of the national school and its most recent representatives.

In the Fournal des artistes, the Marat was presented in a related and equally unselfconscious discourse of transcendence, that of David's 'sublime' transformation of the physically repugnant and politically odious Marat into a figure of beauty and even an object of pity:

Rompant tout à coup avec ses antécédents artistiques, avec ses études chéries de l'antique, il s'est agenouillé devant une nature haineuse, féroce, hideuse, et à force de génie il a su l'ennoblir, sans mentir un instant, l'élever à toute la hauteur des plus beaux ouvrages de l'antiquité. Niera-t-on le pouvoir des arts? ${ }^{38}$

The formal simplicity, realism, and emotional drama of David's treatment of the subject had, he said, achieved an extraordinary reversal of values in which Marat became the hero and Charlotte Corday the criminal. ${ }^{39}$ Grief-stricken at Marat's murder, the painter had abandoned his classical idiom and produced an unprecedented demonstration of the power of pictorial form, when handled by a master, to turn the most base metal of modern history into gold. ${ }^{\circ}{ }^{\circ}$ Marat the

\footnotetext{
37 We remember that Baudelaire had been initially willing to believe that Delacroix might have been excluded from the Bonne-Nouvelle exhibition on account of the organizing committee's failure to see 'la parenté mystérieuse qui l'unit [Delacroix] à l'école révolutionnaire dont il sort' (Euvres complètes, II, 4I3).

${ }_{38}$ 'Exhibition de l'association des artistes', p. 26. Or, as Baudelaire put it, David had transformed Marat into Apollo: 'Quelle était donc cette laideur que la sainte Mort a si vite effacée du bout de son aile? Marat peut désormais défier l'Apollon, la Mort vient de le baiser de ses lèvres amoureuses, et il repose dans le calme de sa métamorphose' (Euvres complètes, II, 4IO).

39 As the Catholic critic Charles Lenormant said of Charlotte Corday: 'Dans les idées de l'époque, la jeune fille, vengeresse des Girondins, [ . . . ] fut considérée comme une héroïne digne des temps antiques' ('Exposition au profit des artistes malheureux', p. 668).

$4^{\circ}$ For a modern formulation of the ways in which David had been constrained by the political circumstances of the time and had turned these constraints into a source of expressive power, see Thomas Crow, Emulation: Making Artists for Revolutionary France (New Haven and London: Yale University Press, i 995), pp. I63-67.
} 
deadly rabble-rouser had shared with Socrates the virtuous citizen the sublime death of the Davidian hero. ${ }^{4}$

In L'Illustration A. J. du Pays drew a parallel between the painting's realism ennobled by David's classical virtues and the example of Michelangelo:

Cela est saisissant de vérité et rendu avec une puissante sobriété d'effet. La simplicité, l'unité qui règnent dans cette peinture, en élèvent le style à une hauteur singulière. La repoussante figure de Marat semble se transfigurer au contact de la mort, et sous le ferme dessin qui le modèle, elle emprunte, malgré sa laideur, une sorte de correction sévère, qui commande l'admiration. Cette tête, autour de laquelle s'enroulent des linges grossiers, me rappelle involontairement Michel-Ange. C'est la même force, la même simplicité, la même largeur, la même science de dessin. ${ }^{42}$

This strategy of enhancing the painting's powerful realistic effects with the distinction associated with the classical idiom as it had been practised by the great masters not only served to channel an incendiary political subject towards a higher aesthetic purpose. It also proposed a greater ambition for realism than that emerging in the annual Salon during the i 840 os and which, before Courbet's emergence at the end of the decade, was principally associated with Adolphe Leleux's scenes of provincial rural life. ${ }^{43}$

Though these examples indicate the extent to which critics supportive of David's cause were prepared to take the idealist route in I 846 in response to a painting whose subject they found difficult, others, unwilling or unable to do the same, were lost for words. Delécluze, for example, was evidently still struggling in 1846 to overcome his distaste of twenty years earlier. When, after his authoritative account of the Mort de Socrate, he turned to the Marat, he became evasive, describing it merely as one of a 'suite de tentatives' undertaken to apply 'la peinture de haut style' to contemporary subjects, of which he provided the list up to the Couronnement de Napoléon, 'l'un des chefs-d'œuvre de ce grand maître', but without saying anything further of the Marat. ${ }^{44}$ Similarly Auguste Jal wrote of the Mort de Socrate: 'Je ne connais pas de plus savante composition dans son œuvre, si remarquable à ce point de vue; je ne connais rien de mieux

\footnotetext{
4I For Lenormant, the analogy-more far-fetched-was with another work by David, not on show in Bonne-Nouvelle, the portrait of Pope Pius VII, which, he said, shared with Marat the artist's celebration of the sublime Catholic virtue of poverty: 'Et, chose étrange! Marat et le Pape l'avait touché par un côté commun. De quelle manière David cherche-t-il à exalter Marat aux yeux du peuple? Par l'aspect de la pauvreté. L'indigence du Pontife lui causait aussi une vive émotion. Ce bon Pape! disait-il un jour dans son atelier en revenant d'une séance que Pie VII lui avait donnée, il est si pauvre! ('Exposition au profit des artistes malheureux', p. 667). This analogy indicates the lengths to which some critics were prepared to go to salvage an idealistic political message from a repellent modern subject.

42 'Exposition des ouvrages de peinture dans la galerie des Beaux-Arts, boulevard BonneNouvelle, 22', L'Illustration, i 4 February i 846, pp. 376-79 (p. 378).

${ }^{43}$ In I 846 , for example, Gautier stated that Leleux's realist painting was 'saine, forte, solide, douée de toutes les simples et rudes qualités du paysan', and that in his 'représentation des types rustiques' the painter had made himself 'le Léopold Robert de la Bretagne et des Pyrénées' 'Salon de I 846', La Presse, 3 April i 846, unpaginated). During the Restoration Robert had specialized in sentimental portrayals of Italian brigands and peasants.

44 'Exposition des ouvrages de peinture'. Mantion ('Enveloppes à Marat David', pp. 208-o9) shows very effectively Delécluze's contribution to the dominant theme in the literature of Marat of the fusion between the real and the ideal, but it is significant that the text which he uses for this purpose is from Delécluze's I 855 history, Louis David, sonécole et son temps, not his article of I 846 .
} 


\section{Facques-Louis David in the Bazar Bonne-Nouvelle}

entendue que cette scène grave, philosophique et pénétrante', ${ }^{45}$ and yet despite the juxtaposition between the Socrates and Marat paintings which the exhibition positively encouraged, he did not mention the Marat at all. For the reviewer in the Démocratie pacifique, the work's political narrative annihilated David's technical performance, albeit exceptional, to the extent that he chose not to discuss it: 'Jamais peut-être David ne porta plus haut les qualités de peintre que dans cet ouvrage extraordinaire. Cependant, à son aspect, le peintre disparaît et l'homme de parti reste seul devant le tribun assassiné'. ${ }^{4}{ }^{6}$ In L'Espérance, Charles ver Huell praised the Mort de Socrate, 'cette belle composition', but went on to say: 'Ce que vous voyez là, en face de Socrate, c'est Marat expirant; mais je ne prétends pas retenir vos regards sur ce hideux spectacle', ${ }^{47}$ and moved on immediately to Les Sabines of I799, which was not in the exhibition. ${ }^{48}$

Turning to pro-republican critics, we find examples of the same eloquent silence. Thoré referred to the realism of the Marat's subject, 'traité d'après nature' by an artist 'convaincu jusqu'au fanatisme' ${ }^{49}$ but the fact of pointing out this combination of realism and political commitment appears to have sufficed in itself, for the remainder of the commentary is purely descriptive. He stated unambiguously that Marat, 'c'est la meilleure peinture de Louis David', ${ }^{\circ}$ but when, in a subsequent article on Ingres's exhibits, he used David's art as a stick with which to beat Ingres for his alleged art-for-art's sake detachment from contemporary political and philosophical issues, there was no mention of Marat. ${ }^{51}$ In L'Artiste, Paul Mantz, presumably one of the 'horde de novateurs' whom the reviewer of the Fournal des artistes had had in mind but also almost certainly one of the 'jeunes vieillards' who represented in art 'les adeptes de la fausse école

45 'Exposition d'ouvrages de l'école française', Moniteur des arts, i 8 January i 846, p. I 94 . This case of self-censorship occurred despite the fact that on the previous page Jal had criticized the unidentified exhibition organizer who had almost decided not to include Greuze's Tête d'enfant for what this official considered to be a serious 'faute de dessin'. It prompted Jal to explain the advantages of showing a master's inferior works, such as the five David portraits on show in the BonneNouvelle exhibition, which he then discussed at length, again without reference to the Marat.

$4^{6}$ 'Exposition de tableaux au profit de la caisse de secours et pensions de la société des artistes, boulevart [sic] Bonne-Nouvelle, 22', Démocratie pacifique, i 5 January i 846, unpaginated.

47 'Exposition d'ouvrages de peinture dans la Galerie des beaux-arts'.

${ }^{48}$ In the same vein but with less enthusiasm for David, we find Fabien Pillet, writing in the journal officiel of the government: 'Parmi les peintures de David, qui figurent au musee temporaire de Bonne-Nouvelle, on remarque, sinon avec intérêt, du moins avec curiosité, la Mort de Marat, dont le sujet nous reporte aux plus effroyables journées de la révolution. La composition en est simple, et il est facile de sentir, au fini de l'exécution, que le peintre avait le malheur de travailler con amore au portrait du monstre dont les bustes ne tardèrent pas à être jetés dans les égouts. Je conçois qu'on attache du prix à ce monument de l'histoire moderne; j'en attacherais beaucoup moi-même à une effigie d'Erostrate ou de Caligula' ('Ouvrages de peinture exposés dans la galerie des beaux-arts, boulevard Bonne-Nouvelle, no 22', Le Moniteur universel, i 6 January i 846, pp. 97-98).

49 'Exposition de la Société des artistes'.

$5 \circ$ Ibid.

${ }_{51}$ 'Pour faire une image, il faut donc avoir un sentiment quelconque qui saisira ensuite le spectateur. Voici la Mort de Socrate, de David; c'est une apothéose: en contemplant ce tableau, il est impossible de ne pas prendre parti pour le philosophe et pour la vérité. La Mort de Socrate, peinte par un sceptique, ne signifierait rien du tout. Voici le Léonidas; courons vite à la frontière défendre la patrie contre l'étranger! Voici le Massacre de Scio, d'Eugène Delacroix; n'êtes-vous pas révolté contre les oppresseurs!' ('Etudes sur la peinture française depuis la fin du i $8^{\text {ème }}$ siècle à propos de l'exposition de la société des artistes. - M. Ingres', Le Constitutionnel, ı March I 846, unpaginated). 
romantique en poésie' referred to by Baudelaire, ${ }^{52}$ could scarcely find any redeeming feature in David's work at all. He dismissed the entire Davidian school for what he called its representation of a pseudo-antique art and society and was willing to make an exception in the case of the Marat only because and in so far as the events of history itself, 'ce jour-là si terrible et si simple', ${ }^{53}$ contained such passion and drama that they infused with character and effect even the Marat, despite what he called its 'anatomical absurdities'. ${ }^{54}$ In this respect, he was merely applying to David reheated criticisms of an alleged incompetence in the science of anatomy that the Davidians had themselves levelled against Ingres.

One critic who might have been expected to review the Bonne-Nouvelle exhibition but who does not appear to have done so was Charles Blanc, art critic of La Réforme and a key figure in the opposition to the July Monarchy's management of the fine arts. ${ }^{55}$ In his Histoire des peintres français au dix-neuvième siècle, published in 1845 , he had described the split within the first Romantic generation in the wake of the revolution of 1830 as that between the representatives of what became known as art for art's sake and those who, in Blanc's words, had sought in painting 'des intentions généreuses, des pensées, de la passion, tout ce qui avait, jusqu'à David, constitué l'originalité de l'école française' and who had not forgotten that 'l'auteur de Léonidas [David's Léonidas aux Thermopyles of I 8I4], pour avoir eu l'enthousiasme de l'idée, était devenu le premier peintre de l'Europe'. ${ }^{5}$ Referring to David's Les Derniers Moments de Lepelletier, Blanc added that the painter had been 'plus vrai, plus expressif encore dans son tableau de Marat expirant, qui est assurément son chef-d'œuvre sous le rapport de l'exécution' 57 but that David had achieved in both paintings that 'beauté absolue qui est de tous les pays et de tous les temps' when, faced with Lepelletier's corpse and Marat's bathtub, 'il oubliait les procédés devenus systématiques pour s'attaquer franchement à la nature elle-même'. ${ }^{8}$ David's legacy would be, Blanc claimed, that of the two forms of history painting to which Delécluze would refer the following year as 'la peinture d'histoire proprement dite' and 'la peinture d'histoire contemporaine', ${ }^{59}$ that is, 'une image passionnée comme le Serment du Feu de paume, ou bien calme, imposante et sublime comme la Mort de Socrate ${ }^{60}$ The Bazar Bonne-Nouvelle exhibition put to the test Blanc's version of David's posterity, when the first of his twin

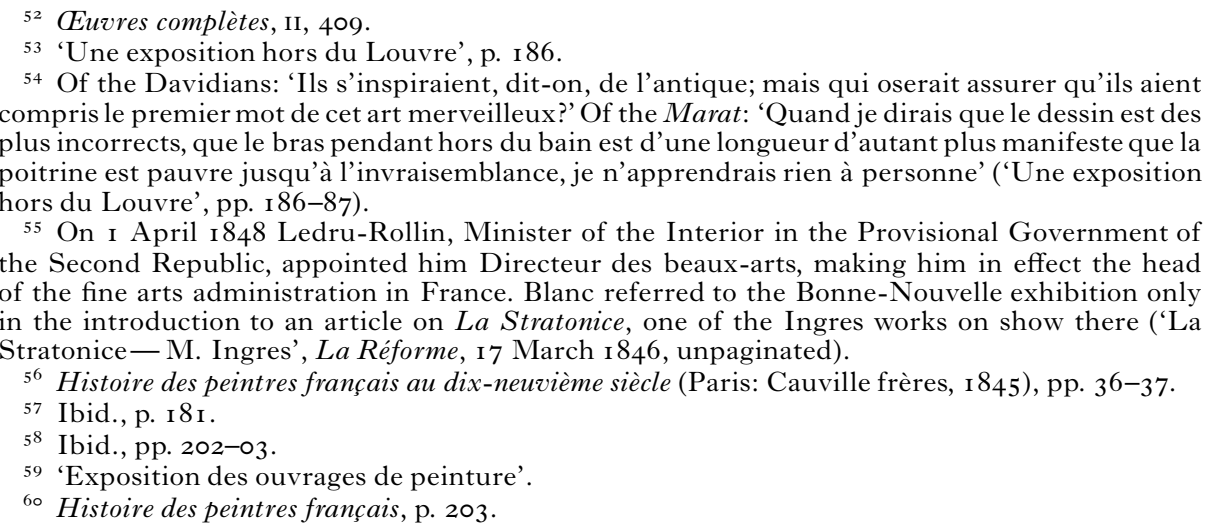




\section{Facques-Louis David in the Bazar Bonne-Nouvelle}

Davidian summits, the passionate image of the Revolution, was represented not by the Serment du Feu de paume but by the Marat.

In January i 846 David's work, albeit only a limited sample, went on public show for the first time for the post-I8I 5 generation and at a time when the history of the French Revolution was the object of major revision. ${ }^{6}$ In this context, the Marat was a revelation, but a problematic one, irrespective of the artistic and political allegiances of those charged with reviewing it. Among republican opponents of the July Monarchy, in particular, the 'painful fascination' which Arnoux had described persisted. One year on, in August i 847, the editor of L'Artiste, Arsène Houssaye, in a gesture presumably designed to reaffirm his review's unaligned traditions, admitted that 'tout en reconnaissant le talent du peintre de la révolution et de l'empire [David], [L'Artiste] a protesté souvent et quelquefois avec trop de sévérité contre les mauvaises tendances de ce grand home, voulant frappper l'école dans le maitre' and that for that reason he had opened its columns to Fleury Richard, 'un des plus intelligens défenseurs de David'. ${ }^{62}$ This committed Davidian went over again David's reform of the French school and the debt owed to him, 'sans s'en douter peutêtre', by 'des Delaroche et même des Delacroix', but took particular issue with the comments on the Bazar Bonne-Nouvelle exhibition made in L'Artiste by an 'ingénieux critique' (Mantz). Referring to David's Roman subjects, he went on:

C'était sans doute au bagne de Toulon qu'il fallait que David eût choisi ses modèles, puisque de toutes ses œuvres c'est Marat assassiné qu'il [Mantz] consent à admirer comme une œuvre simple et grandiose? Mais a-t-il bien senti quel talent et quel génie il a fallu pour idéaliser cette ignoble figure qui, si elle était peinte au daguerréotype, ne pourrait pas se regarder tant elle serait atroce et hideuse $!^{6_{3}}$

Fleury Richard's account of David's idealizing powers which had transformed the atrocious reality of Marat did not, however, prevent L'Artiste from reverting to its anti-Davidian stance a few months later, only weeks before the revolution of 1848 . Clément de Ris, reviewing in January 1848 the third exhibition of the Association des artistes in the Bazar Bonne-Nouvelle, maintained the line which Mantz had taken two years earlier, saying that though the public's appreciation of art was making progress, its tastes were still too governed by 'des préjugés erronés mis à la mode par ce triste David et ses plus tristes successeurs'. ${ }^{64}$ Thoré, in an article calling for the closure of the French Academy in Rome, restated his view that David's art, like that of Poussin, was that of a philosopher or politician, not that of an artist or poet. ${ }^{65}$

6r Four major histories of the Revolutionary period were published in i 847: Louis Blanc's Histoire de la Révolution française (Paris: Langlois et Leclercq, I 847), Esquiros's Histoire des Montagnards (Paris: Lecou, I 847), Lamartine's Histoire des Girondins (Paris: Furne, I 847), and the first volume of Michelet's Histoire de la Révolution française, 5 vols (Paris: Chamerot, I 847-50).

${ }^{62}$ Fleury Richard, 'David et la critique d'art', L'Artiste, i 5 August i 847, pp. 94-95 (p. 95).

63 Ibid., p. 96.

${ }^{64}$ Louis Clément de Ris, 'Beaux-Arts: troisième exposition de l'Association des artistes', $L$ 'Artiste, 23 January I 848 , pp. I 77-80 (pp. I 78, г 80).

65 'A la fin du [dix-huitième] siècle on émigre encore au-delà des Alpes, et David le conventionnel est proclamé roi avant d'avoir voté la mort de Louis XVI. Mais il en est de David comme de Poussin: inspiration française, forme étrangère, esprit convaincu, images de second degré, si l'on peut dire ainsi; philosophe ou politique plutôt qu'artiste et poëte' ('Beaux-arts: de l'école française à Rome', L'Artiste, 6 February i 848 , pp. 2 I 4-i 7 (p. 2 I 7)). 
Within weeks, the newly installed Second Republic initiated, in the form of a competition for a figure of the Republic, the search for new symbols of the republican idea through which to foster an image, both inspiring and reassuring, of a modern, strong, self-confident, and peaceful regime. ${ }^{66}$ In this context, David's Marat was a point of reference to be avoided. Gautier, for example, was certainly in tune with government thinking when, calling in his first article on the Salon of 1848 for new symbols for a new republic, he stated that 'les formules qu'employait la République de l'ancien régime ne peuvent en aucune manière convenir à la nouvelle, et s'en servir serait méconnaître ou fausser les tendances modernes' ${ }^{67}$ Reviewing the contributions to the first round of the republican competition, he summarized the difficulties that the artists had encountered with the iconographical legacy bequeathed by the republic of I 793, noting that 'pourtant la République de 93 n'est pas la République de I848', but adding pointedly: 'il faut l'espérer du moins' ${ }^{68}$ For the new regime in I 848, Delacroix's La Liberté guidant le peuple was still sufficiently problematic for the republic to be no more comfortable about it being on public display in the Musée du Luxembourg than the July Monarchy had been. It was only in 1855 , when the threat of radical politics appeared to have been definitively removed, that the work could be included in Delacroix's contribution to the Exposition Universelle that year, and even then it had required Napoléon III to overrule the objections of his cultural managers. ${ }^{69} \mathrm{Had}$ it been possible for David's Marat to have been in a public collection in $\mathrm{I} 848$, it is a safe bet that it would have shared the fate of La Liberté and been removed to the vaults.

On the other hand, it is true that there was that year what T. J. Clark called 'a new respect for David the Republican'. ${ }^{\circ}$ With Charles Blanc as Director of Fine Arts, this new respect was guaranteed at the highest levels of the republican administration. In October I 848, in his report to the Minister of the Interior on the future of the fine arts in France, Blanc praised the republics of ancient Greece, whose patronage of the arts had resulted in 'des monuments merveilleux dont la beauté impérissable fut remise en honneur dans toute l'Europe par un peintre républicain, le grand David'. ${ }^{71}$ In doing so, he associated David with a positive republican model far removed in time and place from the sad farce of the republican competition and the brutal reality of the June Days. The competition can only have served e contrario to reinforce respect for David's artistic achievement in the Marat while the assumed demise of radical insurgency in June I 848 may

${ }^{66}$ See Marie-Claude Chaudonneret, La Figure de la République: le concours de I848 (Paris: RMN, I987).

${ }_{7}$ 'Salon de I 848, I $^{\text {er }}$ article', La Presse, 22 April i 848, unpaginated. See my book, Théophile Gautier, Orator to the Artists: French Art Fournalism during the Second Republic (Oxford: Legenda, 2007).

68 'Concours pour la figure de la République', La Presse, 2 I May i 848.

${ }^{69}$ On the history of La Liberté see Lee Johnson, The Paintings of Eugène Delacroix, 6 vols (Oxford: Clarendon Press, I98 I-89), I, I 5 I Hélène Toussaint, 'La Liberté guidant le peuple' de Delacroix (Paris: RMN, I982); Arlette Sérullaz et Vincent Pomarède, Eugène Delacroix: 'La Liberté guidant le peuple' (Paris: RMN, 2004).

70 T. J. Clark, The Absolute Bourgeois: Art and Politics in France I848-I85I (London: Thames and Hudson, r 973), p. 70.

${ }_{71}$ 'Rapport au citoyen ministre de l'Intérieur, touchant les beaux-arts et l'avenir qui les attend dans la République', Le Moniteur universel, ı October i 848 , p. 2763. 
well have helped to neutralize the anxieties and distaste that his representation of the ami du peuple had aroused in the Bazar Bonne-Nouvelle two years earlier. When in I 855 Delécluze published the first authoritative history of David and his school, he finally appeared reconciled with the Marat, and with the revision of the Davidian legacy along the lines that Charles Blanc had proposed a decade earlier in his Histoire des peintres français au dix-neuvième siècle:

Jusqu'à la composition du Yeu de Paume et du tableau de Marat, les ouvrages de David peuvent être considérés comme de nobles jeux de son esprit et de son imagination; mais dès que, poussé par l'ouragan révolutionnaire, il mit sur la toile Bailly, Mirabeau, Barnave, Robespierre et enfin Marat, au lieu de consulter les échos vagues et lointains de l'histoire d'Athènes et de Rome, il se sentit tout à coup aux prises avec la réalité, avec la vie qu'il voulait exprimer. Aussi le Marat, s'il n'est pas précisément le chef-d'œuvre du maître, doit-il être regardé comme le premier ouvrage de sa main où percent toute la puissance et l'originalité de son talent. Il avait vu, il avait senti ce qu'il avait peint, et ce fut un trait de lumière qui lui fit envisager son art sous un point de vue tout nouveau. De cet essai, fruit d'un enthousiasme réel, sont résultés d'abord les Sabines, puis le Couronnement, les deux chefs-d'œuvre de David; car malgré la diversité de ces sujets et le peu de rapport qu'ils ont heureusement avec celui du Marat, la composition et l'exécution de ces trois tableaux dérivent du même principe: le renoncement à toute pratique, à toute manière usitée jusque-là par les grands maîtres et par David lui-même, pour obtenir une imitation vraie, simple et noble de la nature. ${ }^{72}$

In the new post-republican phase of French history Delécluze integrated David's Marat into a history of French painting compatible with the apolitical cultural consensus to which the Bonapartist administration aspired. Under this revision, David's achievement was no longer confined to having, in the preRevolutionary work such as the Mort de Socrate, rescued French painting from early eighteenth-century fête galante frivolities. With Marat, David had broken through to a modern, natural idiom by means of which he had scaled the twin summits of what Delécluze had called in I 846 'la peinture d'histoire proprement dite', now represented by the Sabines of I799, and 'la peinture d'histoire contemporaine', ${ }^{73}$ now the Sacre de Napoléon, completed in i 807, two paintings whose composition and execution transcended differences in subject-matter in a manner appropriate to the aspiration to 'une imitation vraie, simple et noble de la nature' in the age of realism. Nearly ten years earlier in the Bazar BonneNouvelle, the painful fascination with which the Marat was received showed both the strength of this aspiration and the obstacles that the painting still appeared at that time to place in the way of its realization.

${ }_{72}$ Louis David, son école et son temps (Paris: Didier, I 855), pp. 405-o6.

73 'Exposition des ouvrages de peinture'. 